\begin{tabular}{|ccl}
\hline 45 & Jurnal Teknologi Kimia Unimal & $\begin{array}{l}\text { Jurnal } \\
\text { Teknologi } \\
\text { Kimia } \\
\text { Unimal }\end{array}$ \\
\hline
\end{tabular}

\title{
Pengaruh Penggunaan Elpiji Sebagai Bahan Bakar Terhadap Unjuk Kerja Motor Bakar Bensin
}

\author{
Asnawi $^{1}$ dan Adi Setiawan ${ }^{2}$ \\ 1,2 Jurusan Teknik Mesin, Universitas Malikussaleh \\ e-mail: asn_awy@yahoo.com
}

\begin{abstract}
Abstrak
Elpiji merupakan salah satu bahan bakar alternatif untuk motor bakar yang lebih ramah lingkungan dibandingkan dengan bensin. Hal ini telah menjadikannya sebagai bahan bakar alternatif untuk mengurangi emisi disektor transportasi. Perubahan jenis bahan bakar digunakan dari bahan bakar bensin menjadi bahan bakar elpiji akan mempengaruhi unjuk kerja yang dihasilkan oleh motor bakar, yang diakibatkan oleh perubahan karaktristik bahan bakar. Dengan demikian, tujuan dari makalah ini adalah membandingkan unjuk kerja yang dihasilkan oleh motor bakar dengan menggunakan bahan bakar elpiji pada kondisi operasi wide open throttle pada berbagai putaran poros motor bakar. Pengujian juga dilakukan dengan menggunakan bahan bakar bensin, yang digunakan sebagai data acuan untuk perbandingan unjuk kerja. Hasil pengujian diperoleh, penggunaan elpiji sebagai bahan bakar dapat meningkatkan meningkatkan efisiensi motor bakar rata-rata sebesar 6,6\%. Hal ini sangat memungkinkan elpiji digunakan sebagai bahan bakar alternatif untuk motor bakar konvensional.
\end{abstract}

Kata kunci : elpiji, torsi, daya, efisiensi

\section{Pendahuluan}

Penggunaan elpiji sebagai bahan bakar alternatif telah mulai meningkat di sektor transportasi khususnya di Indonesia. Umumnya bahan bakar elpiji digunakan pada motor bakar bensin. Perubahan jenis bahan bakar dari bahan bakar cair menjadi bahan bakar gas menjadi permasalahan utama dalam penggunaannya. Perubahan karakteristik bahan bakar juga menjadi permasalahan yang mendasar terhadap unjuk kerja motor bakar. Motor bakar merupakan salah satu media untuk merubah energi kimia menjadi energi termal yang kemudian diubah menjadi energi mekanik (Ferguson and Kirkpatrick, 2001). Ditinjau dari segi emisi yang dihasilkan, pemanfaatan elpiji sebagai bahan bakar alternatif untuk motor bakar menjadi sangat efiktif serta lebih ramah lingkungan dibandingkan dengan bahan bakar bensin. Bensin merupakan campuran $i$-octane 
$\left(\mathrm{C}_{8} \mathrm{H}_{18}\right)$ dan $n$-heptane $\left(\mathrm{C}_{7} \mathrm{H}_{16}\right)$, pada tekanan lingkungan bensin berada dalam fasa cair. Sedangkan elpiji berada dalam fasa gas pada temperatur dan tekanan lingkungan. Komponen utama elpiji adalah merupakan campuran propane $\left(\mathrm{C}_{3} \mathrm{H}_{8}\right)$ dan butane $\left(\mathrm{C}_{4} \mathrm{H}_{10}\right)$, serta mengandung sedikit hidrokarbon ringan lain seperti ethane $\left(\mathrm{C}_{2} \mathrm{H}_{6}\right)$ dan pentane $\left(\mathrm{C}_{5} \mathrm{H}_{12}\right)$ (Borman and Ragland, 1998). Keduanya memiliki karakteristik sangat berbeda, seperti yang ditunjukkan dalam Tabel 1 .

Salah satu kelebihan yang dapat diandalkan penggunaan elpiji sebagai bahan bakar alternatif untuk motor bakar adalah bilangan oktan yang lebih tinggi dibandingkan bensin. Bilangan oktan merupakan parameter dari kualitas bahan bakar bensin, yang menunjukkan daya tahan bahan bakar terhadap autoignition (Borman and Ragland, 1998; Ganesan, 2004; Heywood, 1988). Temperatur autoignition untuk bahan bakar bensin jauh lebih rendah dibandingkan dengan bahan bakar propane dan butane. Hal ini menunjukkan tingginya nilai oktan yang dimiliki oleh bahan bakar, maka motor bakar dapat dioperasikan pada rasio kompresi yang lebih tinggi, sehingga dapat meningkatkan efisiensi motor bakar. Jika autoignition terjadi pada motor bakar SI akan menyebabkan fenomena abnormal selama pembakaran atau disebut dengan ketukan (knocking), yang berdampak pada penurunan efisiensi motor bakar dan dapat terjadi kerusakan komponen utama motor bakar.

Tabel 1. Perbandingan karakteristik bahan bakar (Gumus, 2011)

\begin{tabular}{llll}
\hline Karakteristik & Bensin & Propane & Butane \\
\hline Specific gravity $\left(\mathrm{kg} / \mathrm{m}^{3}\right)$ & 765 & 509 & 585 \\
Lower heating value $(\mathrm{MJ} / \mathrm{kg})$ & 44,04 & 46,34 & 45,56 \\
Boiling point $\left({ }^{\circ} \mathrm{C}\right)$ & $30-225$ & -42 & $-0,5$ \\
Ignition point $\left({ }^{\circ} \mathrm{C}\right)$ & 257 & 510 & 490 \\
Combustion rate $(\mathrm{m} / \mathrm{s})$ & 0,35 & 0,4 & 0,4 \\
Air-fuel ratio & 14,7 & 15,8 & 15,6 \\
Flammability limits $($ Vol. \%) & $1,3-7,6$ & $2,1-9,5$ & $1,5-8,5$ \\
Research octane number & 95 & 111 & 103 \\
\hline
\end{tabular}

Selain itu, kandungan energi persatuan massa yang dimiliki elpiji serta combustion rate/burning speed lebih tinggi dibandingkan dengan bensin. Tingginya combustion rate/burning speed dapat menurunkan durasi pembakaran, 
sehingga dapat menghasilkan tekanan puncak yang lebih tinggi serta motor bakar dapat dioperasikan pada perbandingan campuran yang lebih kurus. Sehingga dapat meningkatkan efisiensi termal dan menurunkan emisi serta konsumsi bahan bakar.

Penurunan emisi gas buang disebabkan oleh tingginya perbandingan $\mathrm{H} / \mathrm{C}$ yang dimiliki oleh elpiji (M. A. Ceviz and Yüksel, 2006). Ini merupakan karakteristik yang sangat baik dijadikan sebagai bahan bakar untuk motor bakar. Flammability limits bahan bakar elpiji lebih tinggi dibandingkan dengan bahan bakar bensin, yang menunjukkan jumlah/keberadaan bahan bakar didalam udara sehingga campuran tersebut mampu terbakar/bereaksi. Hal ini juga menunjukkan penggunaan elpiji sebagai bahan bakar pada motor bakar lebih aman dibandingkan dengan bensin.

\section{Tinjauan Pustaka}

Penelitian mengenai elpiji sebagai bahan bakar kendaraan sudah banyak dilakukan diantaranya, Saleh (2008) melakukan pengujian dengan menggunakan motor diesel dengan menggunakan elpiji dari berbagai Negara dengan komposisi yang berbeda. Variasi komposisi mempengaruhi emisi yang dihasilkan, tingginya kandungan butan dapat menurunkan nitric oxides (NOx) dan tingginya propane dapat menurunkan carbon monoxide $(\mathrm{CO})$, serta terjadinya perubahan temperatur gas buang dan efisiensi pembakaran.

Komposisi elpiji sangat bervariasi, tergantung dari sumbernya dan proses pemisahan yang dilakukan. Hal ini sangat menentukan karakteristik bahan bakar, dimana komposisi bahan bakar yang digunakan sangat menentukan kecepatan reaksi selama proses pembakaran, yang berdampak pada unjuk kerja motor bakar (Ferguson and Kirkpatrick, 2001; Heywood, 1988). Variabel lain yang mempengaruhi kecepatan reaksi pembakaran adalah geometri silinder dan posisi busi dan mungkin berbeda untuk setiap motor bakar (Kodah et al., 2000). Di mana geometri silinder sangat menentukan tingkat turbulensi campuran udara dengan bahan bakar masuk kedalam silinder, sedangkan posisi busi dapat mempengaruhi 
jumlah massa gas yang masuk ke flame front area dan terjadinya reaksi.

Pengaruh komposisi bahan bakar elpiji dengan campuran propane 100\%, 90\%, 70\%, 50\% dan 30\% didalam butane telah dilakukan pengujian oleh (Saleh, 2008). Motor bakar dioperasikan dengan sistem dual fuel, dengan penambahan propane murni dan campuran keduanya kedalam bahan bakar diesel masingmasing sebesar 40\%. Hasil pengujian menunjukkan bahwa fuel conversion efficiency meningkat dengan meningkatnya fraksi propane didalam campuran bahan bakar. Tingginya fraksi propane dapat menurunkan emisi $\mathrm{CO}$ dan sebaliknya terjadi peningkatan $\mathrm{CO}$ dengan meningkatnya fraksi butane didalam campuran, hasil yang sama juga diperoleh oleh Lee et al. (2011). Sedangkan NOx terendah diperoleh pada fraksi butane tertinggi, dan NOx meningkat dengan meningkatnya fraksi propane. Tetapi emisi NO dapat diturunkan dengan mengontrol temperatur elpiji sebelum diinjeksikan kedalam intake manifold (Mehmet Akif Ceviz et al., 2015).

Pengujian dua jenis bahan bakar juga dilakukan oleh Gumus (2011), dengan menambahkan elpiji kedalam bensin yaitu sebesar 0\% (gasoline 100\%), 25\%, $50 \%, 75 \%$ serta $100 \%$ elpiji. Hasil pengujian menunjukkan terjadinya penurunan efisiensi volumetrik proporsional terhadap penambahan elpiji, penurunan terjadi sebesar $17,8 \%, 21 \%, 23,4 \%$ dan 26,5\%. Penurunan efisiensi volumetrik juga terjadi pada pengujian yang dilakukan oleh Erku! et al. (2013) dan Masi dan Gobbato (2012).

Daya dan torsi merupakan salah satu parameter unjuk kerja motor bakar, dimana pengukurannya dapat dilakukan dengan menggunakan dynamometer. Torsi dan daya dari motor bakar diperoleh dari hasil pengkonversian energi termal (panas) hasil pembakaran menjadi energi mekanik. Torsi didefinisikan sebagai besarnya momen putar yang terjadi pada poros output mesin akibat adanya pembebanan, sedangkan daya didefinisikan sebagai besarnya tenaga yang dihasilkan motor tiap satu satuan waktu. Pengukuran torsi motor bakar dengan menggunakan dynamometer yang dihubungkan langsung ke poros engkol (Heywood, 1988). Prinsip kerja dari dynamometer mekanis adalah dengan 
melakukan pembebanan dengan cara melakukan pengereman sehingga menurunkan kecepatan putaran mesin, serta menghasilkan besarnya daya poros pada putaran tertentu. Prony brake merupakan salah satu konsep sederhana yang dapat diterapkan sebagai dasar pengukuran torsi motor bakar, seperti yang ditunjukkan pada pada Gambar 1.

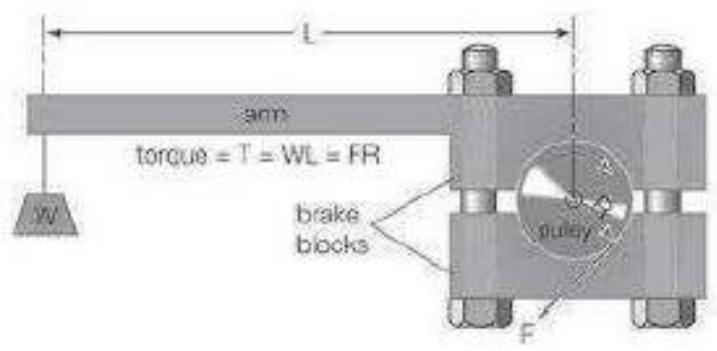

Gambar 1. Prony brake dynamometer

Pengukuran torsi dan daya yang dihasilkan oleh sebuah motor bakar diberikan oleh Ganesan (2004).

$$
T=W L=R F
$$

dimana;

$$
\begin{aligned}
& \mathrm{T}=\text { torsi } \\
& \mathrm{R}=\text { jari-jari poros } \\
& \mathrm{F}=\text { Gaya }
\end{aligned}
$$

Kerja per satu putaran $\quad=2 \pi R F$

$$
\begin{aligned}
\text { Daya } & =\frac{K}{w} \\
& =2 \pi \quad \frac{N}{6}
\end{aligned}
$$

dimana; $\mathrm{N}=$ putaran per menit $(\mathrm{rpm})$

maka brake power,

$$
b=\frac{2 \pi}{60 \times 1000} K
$$


Konsumsi bahan bakar spesifik merupakan sebuah parameter unjuk kerja motor bakar, yang berbanding terbalik dengan efisiensi termal.

$$
b=\frac{k \quad b h a b}{D} \quad p \quad w
$$

maka, Brake thermal efficiency diberikan oleh;

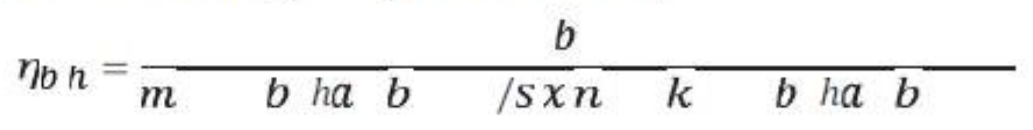

\section{Metode Penelitian}

Motor bakar yang digunakan adalah motor bakar jenis 4 langkah yang didesain untuk bahan bakar petrol/bensin, spesifikasi ditunjukkan dalam Tabel 2. Untuk melakukan penelitian ini diperlukan modifikasi pada pada sistem pemasukan bahan bakar dengan menggunakan vacuum regulator untuk mengontrol perbandingan campuran bahan bakar dan udara.

Persiapan awal yang dilakukan meliputi pemasangan sensor-sensor seperti, thermocouple untuk mengukur temperatur udara masuk serta gas buang. Anemometer untuk mengukur kecepatan aliran udara masuk. Load cell untuk mengukur besarnya gaya pengereman. Serta timbangan digital untuk mengukur konsumsi bahan bakar.

Tabel 2. Spesifikasi Motor bakar yang digunakan

\begin{tabular}{l|l}
\hline Engine Type & Honda GX160-4 Stroke, OHV, Single Cylinder \\
\hline Displacement & $163 \mathrm{cc}$ \\
\hline Bore x Stroke & $68 \times 45 \mathrm{~mm}$ \\
\hline Compression Ratio & $9.0: 1$ \\
\hline Net Power Output* & $4.8 \mathrm{HP}(3.6 \mathrm{~kW}) @, 3,600 \mathrm{rpm}$ \\
\hline Net Torque & $7.61 \mathrm{~b}-\mathrm{ft}(10.3 \mathrm{Nm}) @ 2,500 \mathrm{rpm}$ \\
\hline Ignition System & Transistorized magneto \\
\hline Oil Capacity & 0.58 liters \\
\hline Fuel Tank Capacity & 3.1 liters \\
\hline Fuel & Petrol \\
\hline
\end{tabular}

Sebelum melakukan pengujian terhadap bahan bakar elpiji, pengujian terlebih dahulu dilakukan dengan menggunakan bahan bakar standar yaitu 
premium yang akan digunakan sebagai data acuan untuk perbandingan, dimana sudut percikan api standar untuk bahan bakar premium adalah $10^{\circ}$ sebelum TMA. Kemudian pengujian dilanjutkan dengan menggunakan elpiji sebagai bahan bakar, yang dioperasikan pada berbagai variasi putaran dari $3000 \mathrm{rpm}$ hingga $4500 \mathrm{rpm}$. Semua pengujian dilakukan pada kondisi beban penuh (full load) dengan pembukaan katup throttle $100 \%$ atau sering disebut dengan wide open throttle (WOT). Pengambilan data dilakukan dengan cara pembebanan/pengereman secara bertahap untuk memvariasikan putaran hingga mencapai putaran poros yang diinginkan. Data yang diperoleh dari pengukuran dianalisis untuk mendapatkan unjuk kerja motor bakar. Alur pengujian ditunjukkan pada Gambar 2.

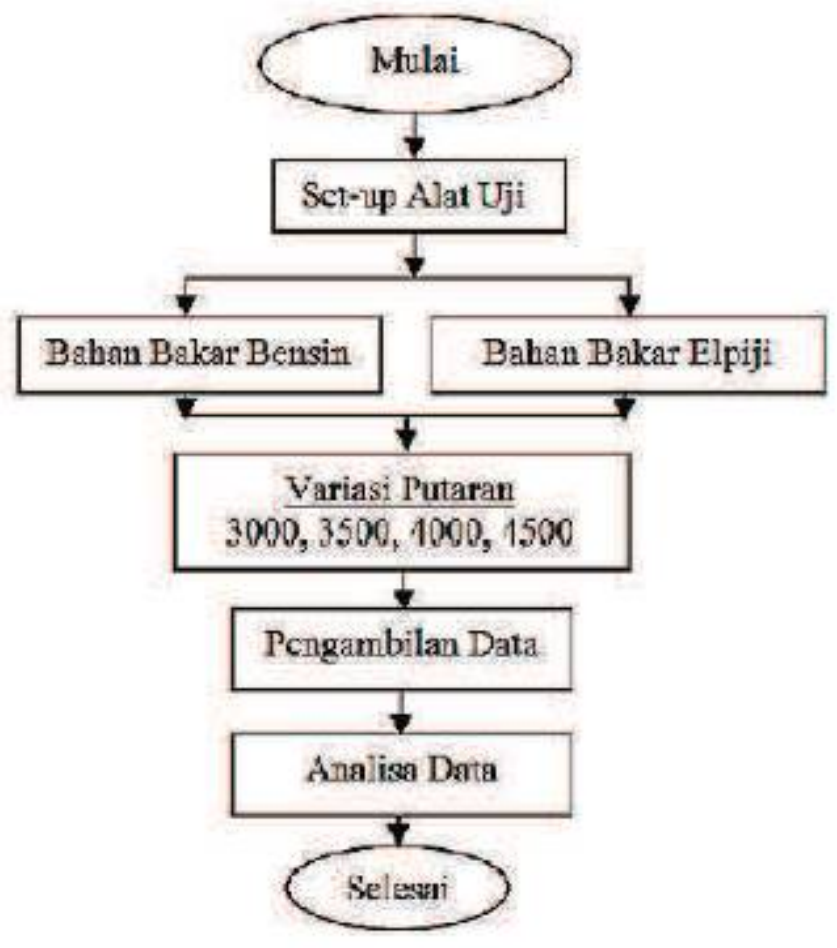

Gambar 2. Diagram alir penelitian

\section{Hasil dan Pembahasan}

Hasil pengujian unjuk kerja motor bakar dengan menggunakan bahan bakar elpiji ditunjukkan pada Gambar 3 - 6. Dimana penggunaan elpiji sebagai bahan bakar pada motor bakar spark ignition (SI) konvensional dapat menurunkan torsi 
dihasilkan rata-rata sebesar 16,4\%, seperti yang ditunjukkan pada Gambar 3. Daya yang dihasilkan juga terjadi penurunan seperti yang ditunjukkan pada Gambar 4, rata-rata sebesar 16,6\%. Hal ini disebabkan oleh terjadinya penurunan efisiensi volumetrik, yang disebabkan oleh berkurangnya massa udara yang masuk ke dalam silinder dengan keberadan volume elpiji yang lebih besar dibandingkan dengan bahan bakar bensin.

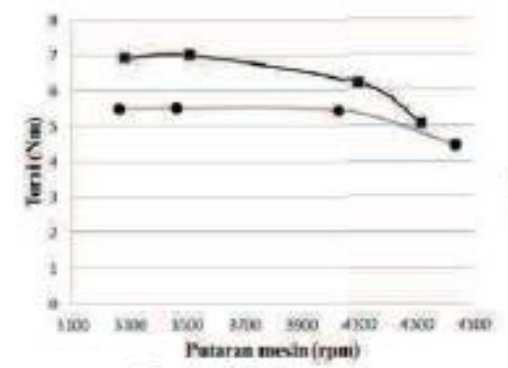

Gambar 3. Torsi vs putaran

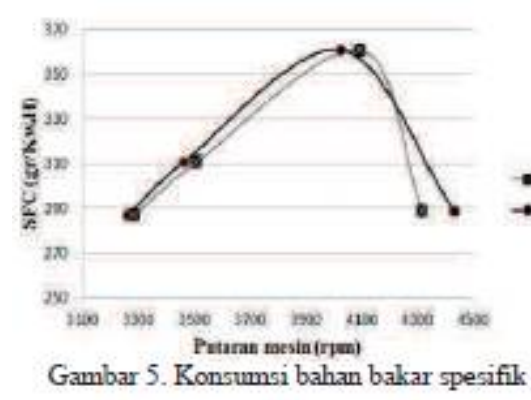

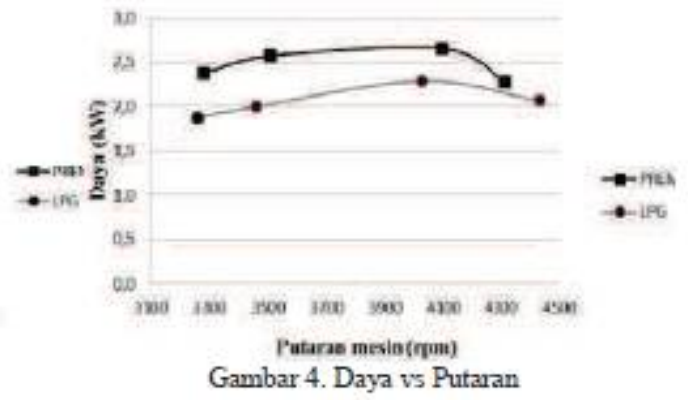

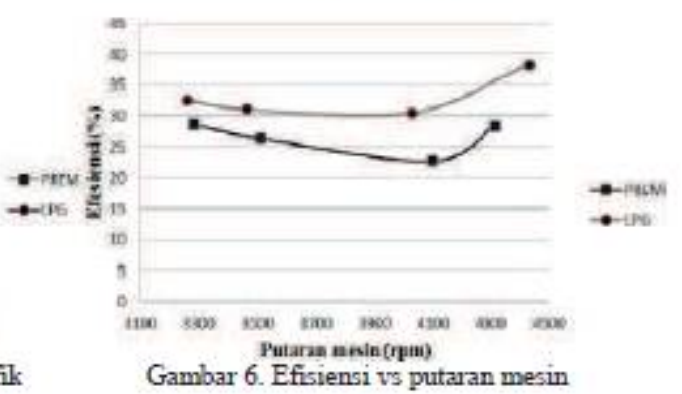

Gambar 5 menunjukkan hasil yang sangat positif untuk menggunakan bahan bakar elpiji sebagai bahan bakar alternatif pengganti bahan bakar bensin, di mana konsumsi bahan bakar menurun rata-rata sebesar 23,4\%. Menurut konsumsi bahan bakar spesifik disebabkan oleh meningkatnya efisiensi dengan menggunakan bahan bakar elpiji, ditunjukkan pada Gambar 6, peningkatan ratarata sebesar $6,6 \%$.

\section{Kesimpulan}

Penggunaan elpiji sebagai bahan bakar alternatif berdampak baik terhadap kerja motor bakar. Penurunan daya dan torsi yang terjadi diakibatkan rendahnya energi input yang masuk ke dalam silinder. Tetapi konsumsi bahan bakar persatuan daya menurun, bakar persatuan daya menurun, yang merupakan 
dampak yang diharapkan untuk meningkatkan efisiensi konversi energi yang terjadi pada motor bakar. Kelemahan yang terjadi akibat dari menurunnya efisiensi volumetrik ini akan dapat dihindari dengan mengunakan motor bakar injeksi untuk system pemasukan bahan bakar.

\section{Daftar Pustaka}

Borman, G. L., and Ragland, K. W. (1998). Combustion Engineering. United States of America: McGraw-Hill.

Ceviz, M. A., Kaleli, A., and Güner, E. (2015). Controlling LPG temperature for SI engine applications. Applied Thermal Engineering, 82(0), 298-305.

Ceviz, M. A., and Yüksel, F. (2006). Cyclic variations on LPG and gasolinefuelled lean burn SI engine. Renewable Energy, 31(12), 19501960.

Erku!, B., Sürmen, A., and Karamangil, M. ". (2013). A comparative study of carburation and injection fuel supply methods in an LPG-fuelled SI engine. Fuel, 107(0), 511-517.

Ferguson, C. R., and Kirkpatrick, A. T. (2001). Internal Combustion Engines, Applied Thermosciences (2nd ed.): Wiley.

Ganesan, V. (2004). Internal Combustion Engines (2nd ed.). Asia: McGraw-Hill Education.

Gumus, M. (2011). Effects of volumetric efficiency on the performance and emissions characteristics of a dual fueled (gasoline and LPG) spark ignition engine. Fuel Processing Technology, 92(10), 1862-1867. 